\title{
Viable microbes in ice: application of molecular assays to McMurdo Dry Valley lake ice communities
}

\author{
MARKUS DIESER ${ }^{1,2}$, ANDREAS NOCKER ${ }^{1,3}$, JOHN C. PRISCU ${ }^{2}$ and CHRISTINE M. FOREMAN ${ }^{1,2 *}$ \\ ${ }^{I}$ Montana State University, Center for Biofilm Engineering, Bozeman, MT 59717, USA \\ ${ }^{2}$ Montana State University, Department of Land Resources and Environmental Sciences, Bozeman, MT 59717, USA \\ ${ }^{3}$ Netherlands Organisation for Applied Scientific Research (TNO), 3704 HE Zeist, The Netherlands \\ *cforeman@montana.edu
}

\begin{abstract}
The permanent ice covers of the McMurdo Dry Valley lakes, Antarctica, are colonized by a diverse microbial assemblage. We collected ice cores from Lakes Fryxell, Hoare and Bonney. Propidium monoazide (PMA) was used in combination with quantitative PCR (qPCR) and denaturing gradient gel electrophoresis (DGGE) to examine membrane integrity of prokaryotes in these extreme environments. PMA selectively penetrates cells with compromised membranes and modifies their DNA resulting in the suppression of PCR amplification. Our results based on analysis of 16S rRNA genes demonstrate that despite the hostile conditions of the Dry Valleys, the permanent ice covers of the lakes support a 'potentially viable' microbial community. The level of membrane integrity, as well as diversity, was higher in samples where sediment was entrapped in the ice cover. Pronounced differences in the fraction of cells with intact and compromised cell membranes were found for Lake Fryxell and east lobe of Lake Bonney, both expressed in differences in DGGE banding patterns and qPCR signal reductions. Limitations in the ability to distinguish between intact or compromised cells occurred in samples from Lake Hoare and west lobe of Lake Bonney due to low DNA template concentrations recovered from the samples.
\end{abstract}

Received 7 January 2010, accepted 26 April 2010, first published online 23 June 2010

Key words: Antarctica, bacteria, live/dead, Propidium monoazide (PMA)

\section{Introduction}

Permanently ice covered lakes are a prominent feature of the McMurdo Dry Valleys, Antarctica, which represents the coldest and driest desert on our planet. Diverse microbial consortia and microplankton dynamics have not only been described in the liquid water columns beneath the ice cover (Goldman et al. 1967, Takacs \& Priscu 1998, Roberts et al. 2000, 2004, Van Trappen et al. 2002, Glatz et al. 2006), but also embedded within the ice cover of these lakes (Fritsen \& Priscu 1998, Olson et al. 1998, Paerl \& Priscu 1998, Priscu et al. 1998, Gordon et al. 2000, Mosier et al. 2007). The primary mode of introducing bacteria and nutrients into the ice cover of these lakes is aeolian transport and deposition from surrounding soils (Psenner \& Sattler 1998, Gordon et al. 2000). It has been demonstrated that soil particles and organic matter serve as water-forming microzones supporting diverse microbial life within the ice covers (Paerl \& Priscu 1998, Priscu et al. 1998, Gordon et al. 2000). Fritsen \& Priscu (1998) reported that cyanobacterial biomass was absent in sediment-free ice covers from lakes Vanda and Morning, stressing the association of bacterial activity with wind-seeded soil particles. Gordon et al. (2000) have shown that the lake ice microbial communities are not exclusively restricted to their icy ecosystem, but are also associated with epilithic and endolithic particles originating from the surrounding terrestrial regions. This seeding mechanism of microorganisms by windblown particles is characteristic of icy habitats and has also been well documented for cryoconites on glaciers in the McMurdo Dry Valleys (e.g. Christner et al. 2003, Porazinska et al. 2004, Foreman et al. 2007).

Once microorganisms are incorporated into the ice, they experience a unique environment characterized by a multitude of seasonally occurring freeze/thaw cycles. These environmental conditions naturally raise questions about the ability of these cells to survive and to maintain membrane integrity as a prerequisite of metabolic activity. While it is known that bacteria play a key role in nutrient cycles and transformation of organic matter in icy systems (Paerl \& Priscu 1998), little is currently known about the viability of these ice-entrapped populations. Previous studies investigated activities associated with aggregates in the permanent ice cover (Olson et al. 1998, Paerl \& Priscu 1998, Priscu et al. 1998). These observed metabolic activities can be assumed to be linked to cells with intact membranes. Although the presence of an intact cell envelope is only an indirect indicator of viability, it implies that the cells have the physiological ability to withstand the harsh environment and the potential for biogeochemical activities, even if they spend considerable time in a dormant or senescent state.

The objective of this study was to gain insight into the extent of membrane damage among microorganisms that 
colonize the ice layers of these perennially ice covered lakes. A relatively new sample pretreatment technology was utilized based on exposure of cells to the chemical propidium monoazide (PMA) prior to subsequent molecular analysis of extracted DNA (Nocker et al. 2006, 2007b). PMA has been reported to only penetrate cells with compromised membranes (Nocker et al. 2006) and once inside the cell, PMA intercalates into the DNA to which it can be covalently cross-linked upon exposure to light. This irreversible DNA modification results in suppression of PCR amplification. In other words, PMA sample treatment allows for selective analysis of the microorganisms with intact membranes in a mixture of live and dead cells. The exposure of cells to challenging environmental conditions present in the ice cover of the McMurdo Dry Valley lakes over extended time periods could induce membrane damage and associated loss of viability. PMA was used in this study both in combination with quantitative PCR (qPCR) and end point PCR-denaturing gradient gel electrophoresis (DGGE) as two distinct downstream DNA analysis methods (Nocker et al. 2006, 2007b) to assess the different membrane conditions.

\section{Materials and methods}

\section{Sample collection and processing}

Five ice core samples were collected in January 2008 from the upper $1.2 \mathrm{~m}$ of Lakes Fryxell (FRX), Hoare (HOR), east lobe of Lake Bonney (ELB), and west lobe of Lake Bonney (WLB), using a $10 \mathrm{~cm}$ diameter SIPRE ice corer. All collections were made near the centres of the lake basins, well away from seasonal moat ice. With the exception of ELB, none of the ice cores collected from the lakes showed visible sediment pockets. Because the bottom cores from ELB contained larger sediment enclosures (1-2 cm across), cores from ELB were further divided into top and bottom sections (each c. $60 \mathrm{~cm}$ ). Before processing, the ice cores were mechanically cleaned by removing approximately $1 \mathrm{~cm}$ of the outer surface using a sterile blade. Cleaned core sections were melted at $4{ }^{\circ} \mathrm{C}$ in acid rinsed and autoclaved glass containers. One litre of ice core meltwater was concentrated via centrifugation $(5000 \mathrm{rpm}$ for $20 \mathrm{~min}$ ) to a final volume of $50 \mathrm{ml}$. Six $\mathrm{ml}$ of sub-sample were removed from each concentrated ice core melt for use in the PMA experiments described below. The remainder of the sample was dried for $48 \mathrm{hrs}$ at $100^{\circ} \mathrm{C}$ to obtain a dry weight. The particulate matter was then combusted at $450^{\circ} \mathrm{C}$ for $5 \mathrm{hrs}$ in a muffle furnace to determine the organic matter (OM) fraction.

\section{PMA Treatment}

For each lake ice sample triplicate assays were prepared in sterile micro-centrifuge tubes. Each replicate consisted of duplicate $1 \mathrm{ml}$ aliquots where one tube was subjected to
PMA treatment following the protocol of Nocker et al. (2007b); the other tube was left untreated. The treated sample (volume of $1 \mathrm{ml}$ ) received $2.5 \mu \mathrm{l}$ of a $20 \mathrm{mM}$ PMA stock solution (phenanthridium, 3-amino-8-azido-5-[(3diethylmethylammonio)propyl]-6-phenyl dichloride, dissolved in 20\% DMSO; PMA from Biotium, Inc., Hayward, CA; final concentration, $50 \mu \mathrm{M})$. Samples were incubated in the dark for $5 \mathrm{~min}$ with occasional gentle mixing. After PMA treatment the tubes were placed horizontally on ice and exposed to bright light (650 W halogen; sealed beam lamp, FCW 120 V, 3200 K; GE Lighting, General Electric Co., Cleveland, $\mathrm{OH}$ ) for $2 \mathrm{~min}$. The light source was placed c. $20 \mathrm{~cm}$ from the sample tubes and the samples were gently shaken during light exposure by tilting the icebox to ensure optimal light penetration. Cells were pelleted at $5000 \mathrm{rpm}$ for $5 \mathrm{~min}$ followed by DNA extraction.

A mixture of Antarctic isolates from the Cotton Glacier (Foreman et al. unpublished) was used as a control sample to demonstrate the efficiency of the PMA treatment. Frozen stock samples of the isolates were transferred to $50 \mathrm{ml}$ tubes and grown to $\log$ phase in $10 \mathrm{ml}$ of $\mathrm{R} 2 \mathrm{~A}$ broth at $4^{\circ} \mathrm{C}$. A $250 \mathrm{ml}$ aliquot was collected from each enrichment, combined, and killed by heating for $15 \mathrm{~min}$ at $72^{\circ} \mathrm{C}$ followed by the addition of isopropanol (final concentration $70 \%$ ) for $10 \mathrm{~min}$. Cells were harvested by centrifugation (5000 rcf for $5 \mathrm{~min}$ ), and the isopropanol supernatant discarded. Pellets were resuspended in $1 \mathrm{ml} 1 \mathrm{X}$ phosphate buffered saline (PBS). The PMA treatment described above was then performed on the control sample.

\section{$D N A$ extraction and $D G G E$}

DNA was extracted using an Ultra Clean Soil DNA Kit (MoBio). Primers 341F (5'-CCTACGGGAGGCAGCAG-3') and 534R (5'-AATACCGCGGCTGCTGG-3') were used for partial amplification of 16S rRNA genes (Muyzer et al. 1996). A 40 base pair GC clamp was added to the 5 ' end of the 341F primer (CGCCCGCCGCGCGCGGCGGGCGGG GCGGGGGCACGGGGGG). PCR reactions were performed in a total volume of $50 \mu \mathrm{l}$ containing $2 \mu \mathrm{l}$ of extracted DNA, $\mathrm{MgCl}_{2}$ buffer (final concentration 1X), Taq Master (final conc. 1X), PCR nucleotide mix (final conc. $800 \mu \mathrm{M}$ ), and

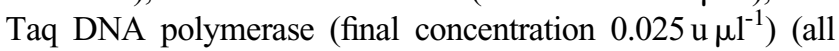
components from 5 Prime, Eppendorf), upstream and downstream primer (final conc. $0.5 \mu \mathrm{M}$ ), and nuclease free water (Promega). The cycling parameters for endpoint PCR included a hot start $\left(94^{\circ} \mathrm{C}\right.$ for $\left.4 \mathrm{~min}\right)$ and a touchdown program. During the touchdown phase, the initial annealing temperature of $65^{\circ} \mathrm{C}$ was decreased by $1^{\circ} \mathrm{C}$ in each of the first eight cycles. For the following 22 cycles the annealing temperature was kept at $58^{\circ} \mathrm{C}$ and a final elongation step was performed at $72^{\circ} \mathrm{C}$ for $10 \mathrm{~min}$. PCR amplifications were carried out in an automated thermal cycler (Mastercycler ep, Eppendorf). In order to achieve sufficient PCR products for DGGE analysis, three PCR reactions for Lakes Hoare and 
west Bonney were conducted and pooled via ethanol precipitation. DGGE was performed with a BioRad D Code $^{\mathrm{TM}}$ system as described by Murray et al. (1996). PCR products were loaded onto $8-12 \%$ polyacrylamide gels. The gel contained a $40-70 \%$ denaturing gradient. The gels ran in $1 \mathrm{X} \mathrm{TAE}$ at $60 \mathrm{~V}$ for $17 \mathrm{hr}$. Gels were stained with SYBR Gold (Invitrogen) for $15 \mathrm{~min}$ and viewed with an Alpha Innotech FluorChem ${ }^{\mathrm{TM}} 8800$ system.

\section{Quantitative PCR}

To amplify the prokaryotic 16S rRNA genes we used primers 1070F (5'-ATGGCTGTCGTCAGCT-3') and 1392R (5'-ACGGGCGGTGTGTAC-3') following the protocol described by Nocker et al. (2007b). Each $25 \mu \mathrm{l}$ qPCR reaction mixture contained $1 \mu l$ of extracted genomic DNA, $12.5 \mu 1$ of $1 \mathrm{X}$ Power SYBR Green PCR Mastermix (Applied Biosystems, Foster City, CA), $1 \mu \mathrm{l}$ of each primer $\left(10 \mathrm{pmol} \mathrm{l}^{-1}\right)$, and $9.5 \mu \mathrm{l}$ molecular grade water (Ambion). The cycling protocol included an initial enzyme activation step of $9 \mathrm{~min}$ at $95^{\circ} \mathrm{C}$, followed by 45 cycles of $30 \mathrm{sec}$ at $95^{\circ} \mathrm{C}, 20 \mathrm{sec}$ at $56^{\circ} \mathrm{C}$, and $25 \mathrm{sec}$ at $72^{\circ} \mathrm{C}$. The analysis was performed using a SmartCycler II (Cepheid, Sunnyvale, CA). The cycle threshold $\left(\mathrm{C}_{\mathrm{T}}\right)$ values were calculated by the SmartCycler II software using a 30-fluorescence unit threshold.

\section{Statistical analysis of DGGE banding patterns}

The structural diversity of the microbial community in the non-PMA treated samples was examined using the Shannon index. Bands were visually detected and scored based upon presence or absence (Gafan et al. 2005). The presence of bands in each sample was denoted by a value of 1 , while a value of zero was assigned when bands were not shared in common. The index was calculated using the following Eq. (1):

$$
\text { Shannon index }\left(\mathrm{H}^{\prime}\right)=-\sum_{i=1}^{s}\left(p_{i}\right) *\left(\log p_{i}\right)
$$

where $s$ is the number of species in the sample and $p_{i}$ is the proportion of species $i$ in the sample.

Table I. Ice core characteristics from McMurdo Dry Valley lakes collected January 2008. Ice cores represent the top $120 \mathrm{~cm}$ of the ice cover. Cores collected from east lobe Bonney were divided into top and bottom $60 \mathrm{~cm}$ sections. Lake Fryxell (FRX), Lake Hoare (HOR), east lobe Lake Bonney (ELB), west lobe Lake Bonney (WLB), and organic matter (OM).

\begin{tabular}{lccccr}
\hline Lake & $\begin{array}{c}\text { Sampling date } \\
2008\end{array}$ & $\begin{array}{c}\text { Ice thickness } \\
(\mathrm{m})\end{array}$ & Matrix & $\begin{array}{c}\text { Sediment } \\
\left(\mathrm{g} \mathrm{l}^{-1}\right)\end{array}$ & $\begin{array}{c}\text { OM } \\
\left(\mu \mathrm{g} \mathrm{l}^{-1}\right)\end{array}$ \\
\hline FRX & 20 Jan. & 4.66 & clear ice & 0.12 & 3.0 \\
HOR & 22 Jan. & 3.34 & clear ice & 0.15 & 0.7 \\
ELB (top) & 27 Jan. & 3.40 & ice and slush & 1.21 & 6.0 \\
ELB (bottom) & 27 Jan. & 3.40 & ice and slush & 5.26 & 25.9 \\
WLB & 30 Jan. & 3.54 & ice and slush & 0.46 & 2.2 \\
\hline
\end{tabular}

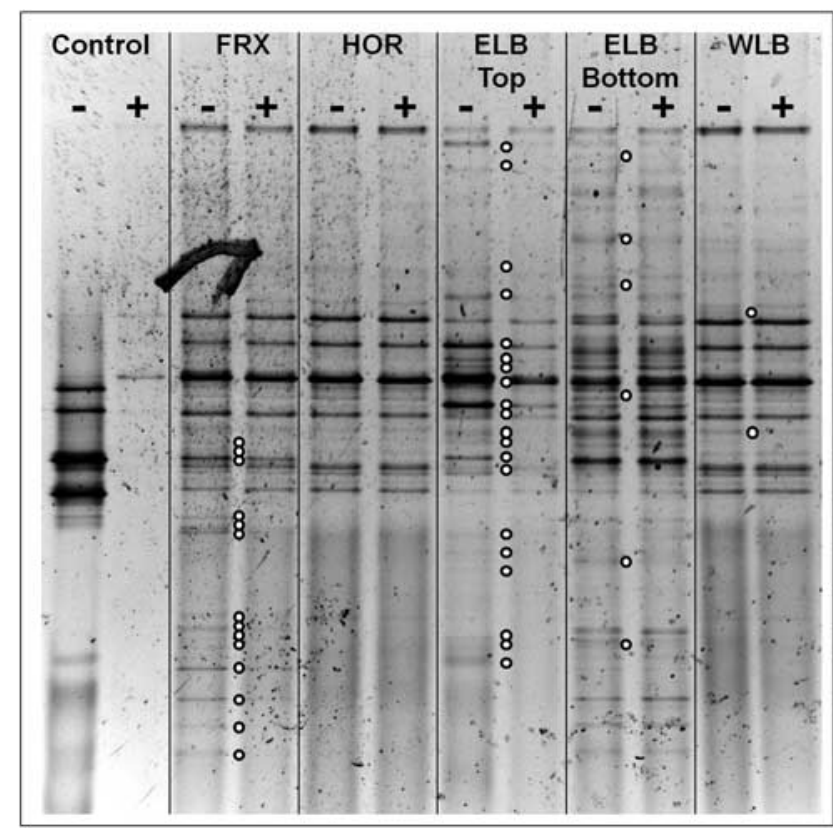

Fig. 1. Differences in DGGE profiles between the microbial communities from McMurdo Dry Valley lake ice core samples (top $120 \mathrm{~cm}$ ) based on 16S rRNA gene amplification. Image colours were inverted, but no other modifications were made to the gels. The control sample consisted of a mixture of cultured Antarctic isolates and served as an indicator for PMA treatment efficiency. For each profile, minus signs (-) indicate samples without PMA treatment; and plus signs (+) indicate PMA treatment. Circles highlight bands that show a difference in intensity caused by the elimination of cells with compromised cell membranes due to the PMA treatment. The comparison of profiles from PMA-treated vs. non-PMA treated samples shows that the ice covers of lakes Fryxell and east lobe Bonney (top $60 \mathrm{~cm}$ ) are comprised of a large fraction of cells with compromised cell walls. Lake Fryxell (FRX), Lake Hoare (HOR), east lobe Bonney (ELB top and bottom), and west lobe Bonney (WLB).

\section{Results}

Ice cover characteristics from each lake are summarized in Table I. Cores from FRX and HOR consisted of solid, clear ice with a few scattered particles. In contrast, cores from ELB and WLB contained large amounts of interstitial water and were composed of $c$. $60 \%$ slush. Fine grained sediments were dispersed throughout the cores; however clearly visible soil aggregates (1-2 cm across) were only found in the bottom $60 \mathrm{~cm}$ core section from ELB. Sediment load and organic matter content within the ice cover of the lakes ranged between 0.12 to $5.26 \mathrm{gl}^{-1}$ and between 0.7 to $25.9 \mu \mathrm{gl} l^{-1}$ respectively (Table I). Highest concentrations of both fractions were found in the bottom core section of ELB.

DGGE profiles (Fig. 1) revealed distinct banding patterns between the individual lakes, with the exception of the HOR and WLB profiles, which were similar. Eleven similar bands were found in each lake profile based upon migration 


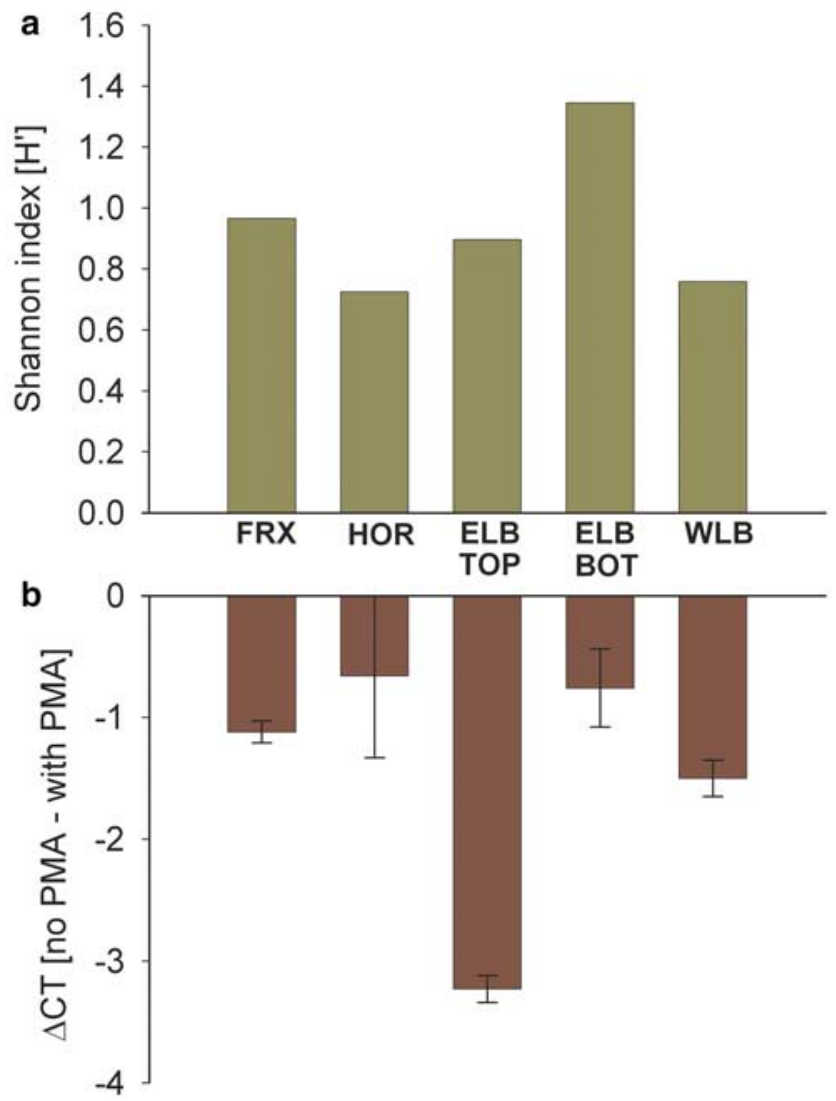

Fig. 2. a. Structural diversity of the microbial community within the ice covers of McMurdo Dry Valley lakes using the Shannon index. b. Calculated qPCR signal reduction for McMurdo Dry Valley lakes. The illustrated signal reduction is the average of three qPCR runs. Signal reduction is a result of the inhibition of DNA amplification from cells with compromised membranes. Higher values indicate a more pronounced difference between intact cells and cells with compromised membranes. Lake Fryxell (FRX), Lake Hoare (HOR), east lobe Lake Bonney (ELB top and bottom), and west lobe Lake Bonney (WLB).

length in the gel. The greatest number of unique bands occurred in the ice core samples from ELB (bottom $60 \mathrm{~cm}$ ), which contained the largest amount of sediment. A pronounced difference in the total number of bands as well as in the banding pattern was apparent between the top and bottom $60 \mathrm{~cm}$ sections from ELB. The elimination of cells with compromised cell membranes due to the PMA treatment resulted in a loss of, or weakened intensity of bands (Fig. 1). Most noticeably, PMA-induced shifts in banding patterns were seen in samples from FRX and ELB Top. Smaller differences between intact and compromised cells were observed for ELB bottom and WLB, while no visible effects were apparent in the community profiles from HOR. The addition of PMA to the killed control sample validated the successful removal of cells with compromised cell membranes.
Differences between DGGE profiles with and without PMA treatment agree well with the data obtained from PMAqPCR. Calculated threshold cycle $\left(\mathrm{C}_{\mathrm{T}}\right)$ values from PMA treated samples were subtracted from the corresponding $\mathrm{C}_{\mathrm{T}}$ values from the non-PMA treated samples. The greatest signal reduction was seen for ELB (top $60 \mathrm{~cm}$ ) with a difference of $3.23 \pm 0.11$ cycles between PMA-treated and untreated aliquots (Fig. 2b). The signal reduction for FRX, which showed the second largest PMA-caused differences in the DGGE profiles, was $1.12 \pm 0.09$ cycles. There was less than one cycle difference between the PMA-treated and nontreated samples for HOR and ELB (bottom $60 \mathrm{~cm}$ ). PMA treatment in the WLB sample resulted in a signal decrease of $1.5 \pm 0.15$ cycles. For the WLB and HOR samples it should be noted that the obtained $\mathrm{C}_{\mathrm{T}}$ values were above 30 cycles, and close to or even larger than the threshold values in the qPCR blank sample (sample with no DNA template). For this reason qPCR signals for HOR and WLB were deemed to be unreliable for further interpretation.

\section{Discussion}

Knowledge of the ratio of live:dead cells provides important information about microbial assemblages in icy environments where the majority of organisms are probably present because of physical processes rather than in situ growth. These subzero environments can preserve cells for millions of years making it difficult to tell if cells are growing slowly in ice grain boundaries (Price 2000) or are simply "freeloaders" passing through the ice as discussed by Priscu et al. (2005). PMA treatment, prior to the DNA extraction and amplification steps, has been suggested to be beneficial in the field of microbial ecology for samples that show substantial differences in the viability of microorganisms (Nocker et al. 2007b); although most applications employing PMA treatment assess disinfection efficacy, where an active killing treatment is applied (Nocker et al. 2007a, Rieder et al. 2008, Lee \& Levin 2009, Wahman et al. 2009) and the difference between living and dead cells can be expected to be significant. Studies utilizing PMA treatment on untreated environmental samples are rare. Nocker et al. (2007b) profiled the microbial community of three environmental samples (municipal wastewater, estuarine benthic mud, and marine sediment) using PMA-DGGE. Only the estuarine samples showed a PMA-caused difference in intensity for one prominent band, while the patterns were identical for municipal wastewater and marine sediment. These finding are similar to the DGGE profiles obtained from HOR and WLB in this study. The effect of PMA treatment on these samples was either not visible or in the case of WLB very small (difference in intensity for two bands). Nocker et al. (2007b) argue that this finding may be explained by the nature of endpoint PCR, as the probability that no significant numbers of membranecompromised cells were contained in those samples is low. 
Whereas $\mathrm{C}_{\mathrm{T}}$ values in $\mathrm{qPCR}$ correlate well with initial DNA template concentrations, the quantitative aspect is lost with increasing cycle numbers in endpoint PCR (Suzuki \& Giovannoni 1996). Higher cycle numbers increasingly favour the amplification of low-abundance templates whose amplification products tend to catch up and finally reach the same (or even higher) levels as amplification products from templates with higher initial abundance. This phenomenon can be seen for many qPCR amplification curves. Thus, different from qPCR, endpoint PCR may not or only partly represent the initial amount of starting templates due to its dependence on the final number of cycles. In order to minimize PCR artefacts and biases, endpoint PCR was carried out for only 30 cycles in this study. The use of fewer cycles proved difficult due to the very low template concentrations typically encountered in these samples. $\mathrm{C}_{\mathrm{T}}$ values for HOR and WLB were above 30 cycles; hence endpoint PCR amplification products (three sets of 30 cycles for these lakes) had to be pooled in order to obtain sufficient product for DGGE analysis.

Aside from these technical considerations, the effect of DNA damage on PCR amplification might minimize differences in PMA-treated and untreated samples. This is particularly important since PMA specifically addresses membrane integrity. Sikorskya et al. (2004) tested the hypothesis that single lesions in the DNA would be sufficient to block polymerase progression on synthetic 90 base oligonucleotides containing normal or modified DNA bases. They concluded that the reduction in polymerase progression depends on the type of DNA damage and the relative position of lesions within the template. Microorganisms that exist in icy environments have endured desiccation, high solar irradiation (especially in surface layers), freezing and thawing, potentially long periods of dormancy, and/or reduced nutrient availability, with all of these being environmental factors that increase the chance of DNA damage. Considering that single lesions in the DNA could already reduce polymerase progression, this could clearly have an impact on DNA amplification. Conversely, significant DNA damage is more likely in dead cells that have lost the ability to repair damaged nucleic acids. In the case of DNA damage in the amplified region, PMA modification might not lead to a further inhibition if the DNA damage per se already impacted the amplification potential. In the case of HOR and WLB samples the initial DNA extracts were most likely insufficient to accurately differentiate between 'viable' and dead cells via endpoint PCR, as emphasized by the need to pool multiple PCR samples for DGGE analysis and the fact that high cycle numbers were required for obtaining sufficient PCR product as indicated by $\mathrm{C}_{\mathrm{T}}$ values. Both low initial DNA concentration and DNA damage lower the probability of seeing PMA-induced differences in profiles for the reasons mentioned before. In contrast to HOR and WLB, a pronounced PMA-caused difference was seen in the DGGE profiles from FRX and ELB (top $60 \mathrm{~cm}$ ) (Fig. 1) suggesting that there existed a significant proportion of membranecompromised cells in these samples. Due to the environmental stresses on bacteria inhabiting the ice covers of the dry valley lakes, this decrease in membrane integrity should not be surprising. From a wide variety of aquatic habitats it is recognized that only a small portion $(<30 \%)$ of the bacteria are viable (Choi et al. 1996, Luna et al. 2002, Davidson et al. 2004).

Despite separation of several kilometres between these lakes, eleven identical DGGE bands were present in all lake ice covers. This accounted for $50 \%$ of the bands identified in DGGE profiles from lakes HOR and WLB. Previous studies have described phylogenetically and metabolically diverse microbial assemblages within regions of the ice covers associated with sediment particles where liquid water inclusions were shown to exist (Fritsen \& Priscu 1998, Paerl \& Priscu 1998, Priscu et al. 1998, Olson et al. 1998, Mosier et al. 2007). It is believed that these particles are of terrestrial origin (Paerl \& Priscu 1998, Priscu et al. 1998, Gordon et al. 2000) and that the strong katabatic winds in the valleys may act as the major dispersal mechanism (Lancaster 2002). This mechanism could lead to phylogenetic commonality among the lake ice covers. However, phylogenetic surveys of different Antarctic soil samples uncovered highly diverse prokaryotic communities (e.g. Smith et al. 2006, Niederberger et al. 2008). Studies on soil samples from the dry valleys showed a high level of species heterogeneity between distinct soil biotopes and altitudes (Smith et al. 2006). Due to the spatial distance between the three lakes studied it seems unlikely that the wind seeded microbial community was solely of the same origin. Although the similarity in banding patterns between WLB and HOR may suggest a homogeneous origin of organisms, banding patterns from FRX and ELB corroborate the assumption of heterogeneous sources. Thus, the occurrence of identical bands more probably indicates the selective mechanism of these environments. Once soil particles melt into the lake ice they are isolated from atmospheric inputs. Since the ice cover could provide more favourable growth conditions (e.g. seasonal liquid water associated with soil particles) compared to the highly saline, arid, and exposed soils, the development of a unique, specialized community could be induced. For instance, little biologically available nitrogen enters these lake ice systems and nitrogen has been found to be the limiting nutrient (Fritsen et al. 1998, Psenner \& Sattler 1998), so microorganisms capable of nitrogen fixation may have a selective advantage (Olson et al. 1998, Paerl \& Priscu 1998). It appears that a less diverse microbial community exists within the ice when larger soil aggregates are absent while diversity flourishes in the presence of larger sediment enclosures as in the case of ELB (bottom $60 \mathrm{~cm}$ ). Calculated diversity indices support this assumption (Fig. 2a). With the exception of the bottom 
section of ELB $\left(\mathrm{H}^{\prime}=1.35\right)$, diversity indices in the ice cores were $<1$. A moderate positive correlation was found between the organic matter content and the Shannon index (Spearman's $\rho=0.4)$. Soil aggregates embedded in the ice create a source of liquid water and nutrients (Paerl \& Priscu 1998). Fritsen et al. (1998) calculated that liquid water associated with these soil aggregates exists for $c .150$ days per year, all within the summer months when continuous sunlight persists. Since nutrient availability and the presence of liquid water are key factors for microbial survival, these aggregates provide an "oasis" for life within the ice cover (Priscu et al. 1998). Although the ice covers on ELB and WLB contained interstitial water and consisted of a slushy matrix, only ELB (bottom $60 \mathrm{~cm}$ ) displayed increased microbial diversity; thus, providing evidence for the stimulating effect of soil aggregates on microbial communities. Presumably the extended presence of liquid water associated with sediments would favour a longer growth season that would allow more cells to propagate. This may result in higher genome copies, which would translate into increased diversity. Fritsen \& Priscu (1998) discovered in ice cores from nine dry valley lakes that more than $98 \%$ of the microalgal biomass was associated with ice core sections that contained sediments. Similarly, results obtained by Paerl \& Priscu (1998) demonstrated that the vast majority $(>95 \%)$ of prokaryotic cells in the ice cover of ELB were confined to sediment aggregates and metabolite exchange between microbial consortia has been implicated (Paerl \& Pinckney 1996, Paerl \& Priscu 1998, Olson et al. 1998). During the summer months when liquid water inclusions exist within the ice this mutually beneficial coexistence would provide a hospitable refuge for growth in what would otherwise appear to be an inhospitable environment. In this coexistence, phototrophs, like cyanobacteria, may fix $\mathrm{N}_{2}$ and provide reduced carbon to the environment. Conversely, heterotrophic bacteria may mineralize potentially limiting nutrients (e.g. $\mathrm{P}$ and $\mathrm{Fe}$ ) and contribute to localized oxygen consumption, which is essential for oxygen sensitive processes such as nitrogen fixation (Paerl \& Priscu 1998, Priscu et al. 1998, Olson et al. 1998). Although we detected a strong correlation between sediment load and the organic matter content (Spearman's $\rho=0.7$ ), organic matter concentrations were generally low (c. $0.5 \%$ relative to dry weight). However, this is a typical feature of dry valley soils where the organic matter content is generally less than $0.1 \%$ (Campbell et al. 1998). Only the percentage of organic matter found within the ice core meltwater from Lake Fryxell was higher $(2.5 \%)$, but still within the range of those reported within cryoconites from Canada Glacier, Antarctica (Foreman et al. 2007). The low atmospheric input of organic matter emphasizes the importance of photosynthetically derived carbon as a source to the heterotrophic microfauna. Thus, the consortial interactions within the ice cover between producers and consumers associated with soil particles appear to be the fundamental life sustaining mechanism which promotes biogeochemical processes and nutrient cycling.

\section{Summary}

Assuming that the DNA amplification in all membranecompromised cells is suppressed by the PMA treatment and that cells with intact membranes are potentially viable, our results provide further support for the existence of viable microbial populations in the ice covers. Life in the ultraoligotrophic ice covers of these lakes is controlled and constrained by annual variations in local climate conditions (e.g. light, temperature) and suitable habitats for microorganisms are driven by internal melt processes in close vicinity to sediments (Priscu et al. 1998). Our results substantiate that there is increased diversity and survivability of organisms found in association with sediment aggregates within the ice covers. However, determining phenotypic characteristics of microorganisms or their role in ecosystem processes are challenging tasks especially in the case of uncultured microbial species. Alternatively, gene clone libraries are used to interpret biogeochemical dynamics thereby applying the phenotypical description of close relatives. Consequently, limiting the molecular fingerprint to the living microbial fraction will greatly help to address important ecological questions (e.g. linking phylogenetic characterizations to biogeochemical processes) more precisely and will provide new insights into ecosystem function in these extreme environments.

\section{Acknowledgements}

We would like to acknowledge the assistance of our McMurdo Dry Valleys LTER and Center for Biofilm Engineering colleagues. Two anonymous reviewers provided suggestions that improved the final manuscript. This work was supported in part by grant NSF OPP 0338342 to CMF.

\section{References}

Campbell, I.B., Claridge, G.G.C., Campbell, D.I. \& Balks, M.R. 1998. The soil environment of the McMurdo Dry Valleys, Antarctica. Antarctic Research Series, 72, 297-322.

Chol, J.W., SHerr, E.B. \& SHerr, B.F. 1996. Relation between presenceabsence of a visible nucleoid and metabolic activity in bacterioplankton cells. Limnology and Oceanography, 41, 1161-1168.

Christner, B.C., Kvitko, B.H. \& Reeve, J. 2003. Molecular identification of bacteria and eukarya inhabiting an Antarctic cryconite hole. Extremophiles, 7, 177-183.

Davidson, A.T., Thomson, P.G., Westwood, K. \& van den Enden, R. 2004. Estimation of bacterioplankton activity in Tasmanian coastal waters and between Tasmania and Antarctica using stains. Aquatic Microbial Ecology, 37, 33-45.

Foreman, C.M., Sattler, B., Mikucki, J.A., Porazinska, D.L. \& Priscu, J.C. 2007. Metabolic activity and diversity of cryoconites in the Taylor Valley, Antarctica. Journal of Geophysical Research, 112, 10.1029/ 2006JG000358. 
Fritsen, C.H., Adams, E.E., McKay, C.P. \& Priscu, J.P. 1998. Permanent ice covers of the McMudo Dry Valley lakes, Antarctica: liquid water contents. Antarctic Research Series, 72, 269-280.

Fritsen, C.H. \& Priscu, J.C. 1998. Cyanobacterial assemblages in permanent ice covers on Antarctic lakes: distribution, growth rate, and temperature response of photosynthesis. Journal of Phycology, 34, $587-597$.

Gafan, G.P., Lucas, V.S., Roberts, G.J., Petric, A., Wilson, M. \& Spratt, D.A. 2005. Statistical analyses of complex denaturing gradient gel electrophoresis profiles. Journal of Clinical Microbiology, 43, 3971-3978.

Glatz, R.E., Lepp, P.W., Ward, B.B. \& Francis, C.A. 2006. Planktonic microbial community composition across steep physical/chemical gradients in permanently ice-covered Lake Bonney, Antarctica. Geobiology, 4, 53-67.

Goldman, C.R., Mason, D.T. \& HobBie, J.E. 1967. Two Antarctic desert lakes. Limnology and Oceanography, 12, 295-310.

Gordon, D.A., Priscu, J. \& Giovannoni, S. 2000. Origin and phylogeny of microbes living in permanent Antarctic lake ice. Microbial Ecology, 39, 197-202.

LANCASTER, N. 2002. Flux of eolian sediment in the McMurdo Dry Valleys, Antarctica: a preliminary assessment. Arctic Antarctic and Alpine Research, 34, 318-323.

LEE, J.L. \& LEvin, R.E. 2009. A comparative study of the ability of EMA and PMA to distinguish viable from heat killed mixed bacteria from fish fillets. Journal of Microbiological Methods, 76, 93-96.

Luna, G.M., Manini, E. \& Danovaro, R. 2002. Large fraction of dead and inactive bacteria in coastal marine sediments: comparison of protocols for determination and ecological significance. Applied and Environmental Microbiology, 68, 3509-3513.

Mosier, A.C., Murray, A.E. \& Fritsen, C.H. 2007. Microbiota within the perennial ice cover of Lake Vida, Antarctica. FEMS Microbiology. Ecology, 59, 274-288.

Murray, A.E., Hollibaugh, J.T. \& Orrego, C. 1996. Phylogenetic compositions of bacterioplankton from two California estuaries compared by denaturing gradient gel electrophoresis of $16 \mathrm{~S}$ rDNA fragments. Applied and Environmental Microbiology, 62, 2676-2680.

Muyzer, G., Hottentrager, S., Teske, A. \& Waver, C. 1996. Denaturing gradient gel electrophoresis of PCR-amplified 16S rDNA. A new molecular approach to analyze the genetic diversity of mixed microbial communities. In AkKermans, A.D.L., van Elsas, J.D. \& DE Bruijn F.J., eds. Molecular microbial ecology manual 3.4.4. Dordrecht: Kluwer, $1-23$.

Niederberger, T.D., Mcdonald, I.R., Hacker, A.L., Soo, R.M., Barrett, J.E., WALL, D.H. \& CARY, S.C. 2008. Microbial community composition in soils of northern Victoria Land, Antarctica. Environmental Microbiology, 10, 1713-1724.

Nocker, A., Cheung, C.Y. \& CAMPER, A.K. 2006. Comparison of propidium monoazide with ethidium monoazide for differentiation of live vs. dead bacteria by selective removal of DNA from the cells. Journal of Microbiological Methods, 67, 310-320.

Nocker, A., Sossa, K.E. \& CAMPer, A.K. 2007a. Molecular monitoring of disinfection efficacy using propidium monoazide in combination with quantitative PCR. Journal of Microbiological Methods, 70, 252-260.

Nocker, A., Sossa-Fernandez, P., Burr, M.D. \& CAmper, A.K. 2007b. Use of propidium monoazide for live/dead distinction in microbial ecology. Applied and Environmental Microbiology, 73, 5111-5117.
Olson, J.B., Steppe, T.F., Litaker, R.W. \& Paerl, H.W. 1998. N 2 -fixing microbial consortia associated with the ice cover of Lake Bonney, Antarctica. Microbial Ecology, 36, 231-238.

PAerL, H.W. \& Pinckney, J.L. 1996. A mini-review of microbial consortia: their roles in aquatic production and biogeochemical cycling. Microbial Ecology, 31, 225-247.

PAerL, H.W. \& Priscu, J.C. 1998. Microbial phototrophic, heterotrophic and diazotrophic activities associated with aggregates in the permanent ice cover of the Lake Bonney, Antarctica. Microbial Ecology, 36, 221-230.

Porazinska, D.L., Fountain, A.G., Nylen, T.H., Tranter, M., Virginia, R.A. \& WALL, D.H. 2004. The biodiversity and biogeochemistry of cryoconite holes from McMurdo Dry Valley glaciers, Antarctica. Arctic, Antarctic and Alpine Research, 36, 84-91.

Price, B.P. 2000. A habitat for psychrophiles in deep Antarctic ice. PNAS, 97, 1247-1251.

Priscu, J.C., Adams, E.E., Paerl, H.W., Fritsen, C.H., Dore, J.E., Lisle, J.T., Wolf, C.F. \& Mikucki, J.A. 2005. Perennial Antarctic lake ice: a refuge for cyanobacteria in an extreme environment. In CASTELLO, J.D. \& Rogers, S.O., eds. Life in ancient ice. Princeton, NJ: Princeton University Press, 22-49.

Priscu, J.C., Fritsen, C.H., Adams, E.E., Giovannoni, S.J., Paerl, H.W., McKay, C.P., Doran, P.T., Gordon, D.A., Lanoll, B.D. \& Pinckney, J.L. 1998. Perennial Antarctic lake ice: an oasis for life in a polar desert. Science, 280, 2095-2098.

Psenner, R. \& Sattler, B. 1998. Life at the freezing point. Science, 280, 2073-2074.

Rieder, A., Schwartz, T., Schön-Hölz, K., Marten, S.M., Süss, J., Gusbeth, C. \& Kohnen, W. 2008. Molecular monitoring of inactivation efficiencies of bacteria during pulsed electric field treatment of clinical wastewater. Journal of Applied Microbiology, 105, 2035-2045.

Roberts, E.C., Priscu, J.C. \& Laybourn-Parry, J. 2004. Microplankton dynamics in a perennially ice-covered Antarctic lake - Lake Hoare. Freshwater Biology, 49, 853-869.

Roberts, E.C., Laybourn-Parry, J., McKnight, D. \& Novarino, G. 2000. Stratification and dynamics of microbial loop communities in Lake Fryxell, Antarctica. Freshwater Biology, 44, 649-661.

Sikorskya, J.A., Primeranoa, D.A., Fengera, T.W. \& Denvir, J. 2004. Effect of DNA damage on PCR amplification efficiency with the relative threshold cycle method. Biochemical and Biophysical Research Communications, 323, 823-830.

Smith, J.J., Tow, L.A., Stafford, W., Cary, C. \& Cowan, D.A. 2006. Bacterial diversity in three different Antarctic cold desert mineral soils. Microbial Ecology, 51, 413-421.

Suzuki, M.T. \& Giovannoni, S.J. 1996. Bias caused by template annealing in the amplification of mixtures of $16 \mathrm{~S}$ rRNA genes by PCR. Applied and Environmental Microbiology, 62, 625-630.

TAKaCs, C.T. \& PrIscu, J.C. 1998. Bacterioplankton dynamics in the McMurdo Dry Valley lakes: production and biomass loss over four seasons. Microbial Ecology, 36, 239-250.

Van Trappen, S., Mergaert, J., van Eygen, S., Dawyndt, P., Cnockaert, M.C. \& SwINGS, J. 2002. Diversity of 746 heterotrophic bacteria isolated from microbial mats from ten Antarctic lakes. Systematic and Applied Microbiology, 25, 603-610.

Wahman, D.G., Wulfeck-Kleier, K.A. \& Pressman, J.G. 2009. Monochloramine disinfection kinetics of Nitrosomonas europaea using propidium monoazide quantitative PCR (PMA-qPCR) and LIVE/ $\mathrm{DEAD}(\mathrm{R})$ BacLight methods. Applied and Environmental Microbiology, 75, 5555-5562. 